\title{
Strategi Pendidikan Karakter Anak Usia Dini Menggunakan Perangkat Kepribadian Genetik STIFIn
}

\author{
Arief Setiawan1, Rony Sandra Yofa Zebua ${ }^{1 凶}$, Sunarti $^{2}$ \\ Pendidikan Islam, Universitas Islam Bandung, Indonesia (1) \\ Sains Manajemen, Institut Teknologi Bandung, Indonesia(2) \\ DOI: $\underline{10.31004 / \text { obsesi.v6i3.1860 }}$
}

\begin{abstract}
Abstrak
Pendidikan karakter membutuhkan metode dan pendekatan yang sinkron dengan potensi atau kepribadian anak didik. Perangkat kepribadian genetik STIFIn dapat membantu guru memahami potensi anak didik sehingga dapat dimanfaatkan untuk membantu membangun karakter siswa. Penelitian ini bertujuan mengkaji peranan STIFIn dalam pendidikan karakter dan mengidentifikasi bagaimana strategi dalam mengimplementasikannya. Penelitian dilakukan di PAUD Lare Alit Bandung, dengan menggunakan teknik wawancara mendalam untuk mendapatkan data. Hasil penelitian menunjukkan bahwa terdapat beberapa langkah strategi yang diperlukan dalam mengimplementasikan STIFIn. Tahapannya berupa persiapan guru terhadap pendekatan STIFIn dan mengidentifikasi kepribadian genetik peserta didik. Tahap kedua yaitu menentukan pendekatan dan metode yang tepat berdasarkan kepribadian genetik peserta didiknya, mengimplementasikan dalam kegiatan pembelajaran dan kegiatan evaluasi bekerjasama dengan orangtua di rumah. Penelitian ini menunjukkan implementasi STIFIn dapat membantu guru dalam mengidentifikasi potensi anak didik dan mengoptimalkannya.
\end{abstract}

Kata Kunci: karakter; pendidikan karakter; pembentukan karakter anak usia dini

\begin{abstract}
Character education requires proper methods and approaches to develop students' personalities. STIFIn genetic personality tool can help teachers to understand their students' potencies so that it can be beneficial to build students' character. This study aimed at analyzing the role of STIFIn in character education and identified the implementation strategy. The study was conducted in PAUD Lare Alit Bandung, by applying in-depth interviews with the key stakeholders, the results showed some steps required to implement STIFIn. The steps were preparation of the teachers' toward STIFIn tools and students' genetic personality identification. The second step was to determine the methods and approaches according to the genetic personality identification and implement them into the learning process. There was also an evaluation activity by cooperating with the parents. This study showed that STIFIn implementation is useful to help the teachers identify their students' potency and optimize them.
\end{abstract}

Keywords: character; character building; character building of early childhood

Copyright (c) 2021 Arief Setiawan, et al.

$\triangle$ Corresponding author:

Email Address : ronysyzebua@gmail.com (Bandung, Jawa Barat, Indonesia)

Received 13 July 2022, Accepted 30 October 2021, Published 6 November 2021 


\section{PENDAHULUAN}

Karakter atau akhlak memegang peranan yang penting dan utama sejak zaman dahulu (Helmawati, 2017, p. 2). Karakter menjadi sumber kekuatan dan kestabilan suatu masyarakat dan bangsa (Tafsir, 2018, p. 68). Oleh karena itu, pembentukan karakter seharusnya menjadi perhatian utama setiap kelompok masyarakat dan bangsa. Ini sejalan dengan ajaran agama Islam yang menempatkan pembentukan dan pengembangan karakter sebagai komponen penting (Al-Qasimi, 2010; Daradjat, 2018). Pembentukan karakter dalam agama Islam merupakan hal mendasar yang dilakukan dari awal dan sepanjang hayat (Helmawati, 2017; Jawas, 2019). Hal ini senada dengan kebijakan pemerintah Indonesia yang telah menetapkan penguatan karakter menjadi salah satu tujuan prioritas dalam program kurikulum nasional (Kemdikbud, 2017).

Makna karakter memiliki cakupan yang luas, yaitu sebagai moral (Lickona, 1991, p. 39) atau akhlak (Tafsir, 2018, p. 65; Zuchdi et al., 2012, p. 16), etika (Josephson \& Hanson, 2004, p. 4; Tafsir, 2018, p. 65), budi pekerti (Tafsir, 2018, p. 65) dan kepribadian seseorang (Zuchdi et al., 2012, p. 16). Oleh karena itu, karakter merupakan kondisi jiwa yang stabil (Lickona, 1991, p. 51) dan melekat pada diri seseorang (Mustoip et al., 2018) serta mendorongnya untuk melakukan perilaku tertentu secara spontan (Josephson \& Hanson, 2004, p. 4).

Kegiatan pendidikan karakter mengacu pada serangkaian proses dan interaksi yang terkait kognitif, afektif, dan psikomotorik (Zuchdi et al., 2012, p. 16), yang diharapkan dapat menanamkan nilai-nilai, mengembangkan motivasi dan kompetensi yang proaktif (Lickona et al., 2007). Maka, pendidikan karakter dapat dikatakan sebagai proses memahami hal yang baik dan membiasakan dalam cara berpikirnya, menghendaki perilaku baik dan memiliki dalam hatinya, melakukan tindakan positif dan membiasakannya (Frye et al., 2002, p. 3; Lickona, 1991, p. 51). Menurut Lickona (1991), tiga hal di atas dirumuskan sebagai 3 elemen karakter yang saling berhubungan timbal balik, yakni moral knowing sebagai daya nalar, perasaan moral moral feeling sebagai daya rasa, dan moral action sebagai daya tindakan. Interaksi timbal balik elemen tersebut ditunjukkan pada Gambar 1.

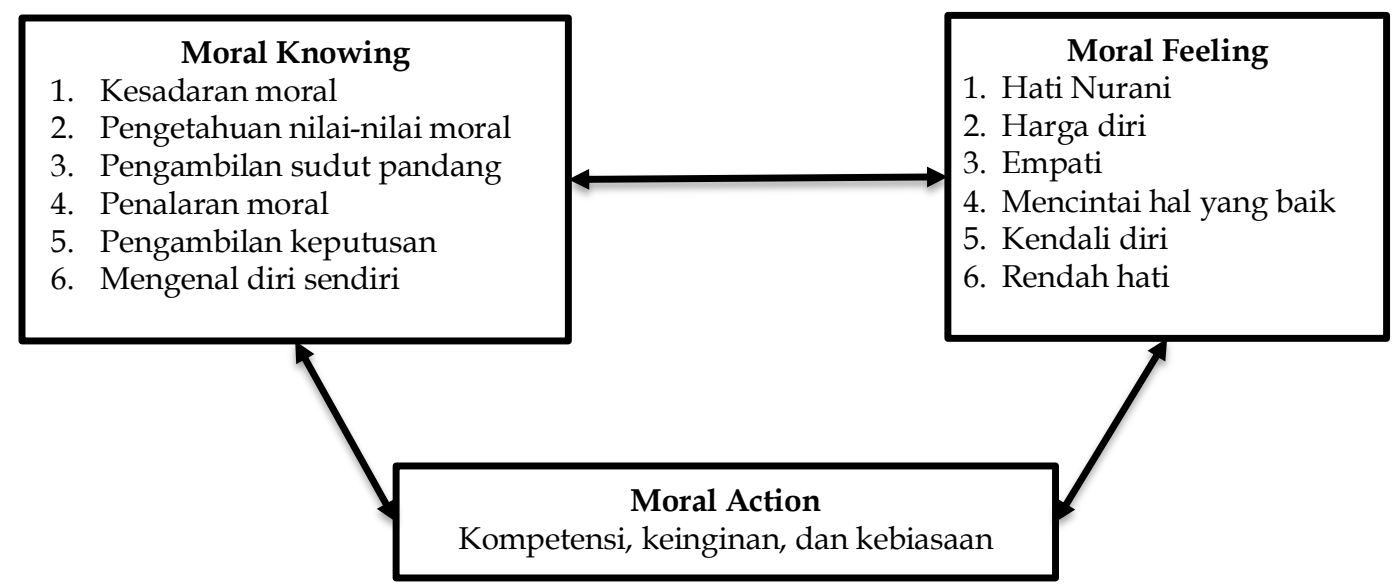

Gambar 1. Interaksi Elemen Karakter (Lickona, 1991, p. 53)

Karakter merupakan potensi bawaan yang dapat dibentuk dan diubah melalui pengkondisian lingkungan secara intensif dan teratur, di antaranya lingkungan keluarga dan lingkungan pendidikan (Al-Qasimi, 2010; Daradjat, 2018; Tafsir, 2018; Zebua \& Sunarti, 2020). Pengkondisian lingkungan pendidikan akan memengaruhi perilaku individu dan mendorong terjadi proses pembentukan karakter tertentu (Chen, 2011; Powell et al., 2009; Zebua, 2021). Pendidikan karakter berfungsi sebagai lingkungan yang akan memberikan pengaruh pada perubahan perilaku individu. Hal ini diuraikan di antaranya dalam Social Cognitive Theory (SCT) oleh Bandura, yang merumuskan tiga variabel dalam perubahan perilaku yaitu perilaku tertentu, lingkungan dan personal (Ormrod et al., 2017, p. 344; Santrock, 2011, p. 235). Ketiga variabel tersebut berinteraksi secara kompleks dan membentuk hubungan timbal balik 
(Dewar et al., 2012; Schunk \& DiBenedetto, 2020). Hubungan ketiga variabel SCT ditunjukkan pada Gambar 2.

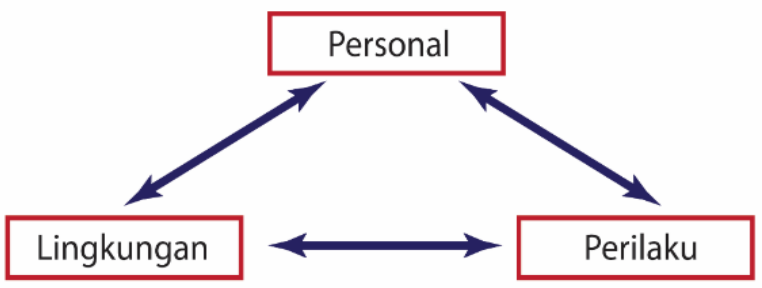

Gambar 2. Teori Kognitif Sosial (Santrock, 2011, p. 235)

Penerapan pendekatan yang tepat dan disesuaikan dengan potensi anak didik akan mewujudkan lingkungan pendidikan karakter yang optimal (Zebua \& Suhardini, 2021). Salah satu usaha yang dapat diupayakan agar mewujudkannya, yaitu dengan menggunakan STIFIn Genetic Personality atau biasa dikenal dengan istilah STIFIn.

STIFIn merupakan sebuah perangkat yang digunakan untuk membantu mendeteksi potensi kepribadian genetik seseorang (Poniman, 2009). Informasi kepribadian genetik tersebut dapat digunakan untuk membentuk lingkungan yang tepat dalam lingkup pendidikan. Potensi genetik yang diukur oleh STIFIn adalah potensi diri yang dibawa sejak lahir dan cenderung konstan sepanjang hayat (Poniman \& Ariezta, 2019, p. 83; Poniman \& Mangussara, 2013, p. 10). Hasil deteksi dan identifikasi tersebut dapat digunakan untuk pengembangan diri seseorang termasuk dalam pembentukan karakternya (Asbari et al., 2019).

STIFIn memiliki landasan ilmiah yaitu pendekatan psikologi analitik yang dirintis oleh Carl Gustav Jung dan mengompilasikannya dengan teori Whole Brain oleh Ned Herrmann serta teori Triune Brain oleh Paul MacLean (Poniman, 2009). Kepribadian genetik dalam STIFIn terbentuk dari gabungan mesin kecerdasan dan kemudi kecerdasan. Mesin kecerdasan dalam STIFIn terdiri dari Sensing, Thinking, Intuiting, Feeling, dan Insting (Agung \& Rustandi, 2017, p. 46), sedangkan kemudi kecerdasan terdiri dari introvert dan ekstrovert (Poniman, 2009). Dari lima mesin kecerdasan, hanya Insting yang tidak memiliki kemudi kecerdasan, sehingga karakteristik insting cenderung bereaksi spontan. Dengan demikian, terdapat 9 jenis kepribadian genetik, yakni Sensing extrovert (Se), Sensing introvert (Si), Thinking extrovert (Te), Thinking introvert (Ti), Intuiting extrovert (Ie), Intuiting introvert (Ii), Feeling extrovert (Fe), Feeling introvert (Fi), dan Insting (In). Konsep ini menjadi paradigma identifikasi kepribadian genetik STIFIn, yang hanya ada satu kepribadian genetik yang dominan dan menjadi fokus pengembangan (Poniman, 2009).

Dengan demikian, implementasi STIFIn dalam pembentukan karakter adalah memberikan lingkungan yang tepat berdasarkan kesesuaian dengan kepribadian genetik setiap orang kepribadiannya (Poniman \& Hadiyat, 2015, p. 66). Berdasarkan STIFIn, setiap individu terbentuk oleh sekitar $20 \%$ faktor genetik dalam dirinya dan $80 \%$ faktor lingkungan yang memengaruhinya (Poniman \& Ariezta, 2019). Sehingga karakteristik seseorang merupakan gabungan antara faktor bawaan lahir dan pengaruh dari lingkungan sekitarnya. Sehingga, ketika metode penempaan individu berbasis STIFIn ini diterapkan dalam pendidikan karakter, diharapkan pembentukan karakter pada anak didik akan lebih efektif.

Ada beberapa penelitian yang berkaitan dengan penggunaan STIFIn, baik dalam pemanfaatannya secara umum ataupun dalam konteks pendidikan karakter. Namun umumnya penelitian-penelitian tersebut hanya membahas pemanfaatannya saja, tidak membahas hingga bagaimana strategi dalam mengimplementasikan, khususnya dalam konteks pendidikan karakter. Seperti misalnya, penggunaan STIFIn untuk pengenalan minat, bakat siswa (Alindra, 2018), karakteristik genetik siswa (Asbari et al., 2019; Baharun \& Adhimiy, 2019), tenaga pendidik (Amri \& Rahman, 2020), guru (Sundari et al., 2019), dan 
pemanfaatan STIFIn dalam konteks umum (Alindra, 2018; Oktaviany \& Halim, 2020). Penelitian-penelitian tersebut mengkaji beberapa pemanfaatan STIFIn untuk pemilihan metode yang tepat dalam pengembangan bakat (Alindra, 2018), penentuan pola asuh secara umum di sekolah inklusi (Oktaviany \& Halim, 2020), peningkatan kecerdasan santri dalam memahami pelajaran dan memotivasi diri sendiri (Baharun \& Adhimiy, 2019), peningkatan kemampuan dan motivasi kinerja dalam lingkungan pendidikan (Amri \& Rahman, 2020). Penelitian oleh Asbari et al. (Asbari et al., 2019), mengkaji pemanfaatan STIFIn di tingkat PAUD, namun hanya sebatas menyajikan hubungan kepribadian genetik terhadap karakter anak didiknya. Belum ditemukan penelitian yang membahas secara terperinci tentang bagaimana strategi dalam memanfaatkan STIFIn untuk diterapkan dalam mendukung pendidikan karakter siswa, termasuk pendidikan di tingkat PAUD.

Berdasarkan penjabaran di atas, maka terdapat research gaps dalam topik terkait pemanfaatan STIFIn dalam pendidikan karater yang akan diisi oleh penelitian ini. Penelitian ini bertujuan untuk menginvestigasi secara khusus tentang strategi pendidikan karakter berbasis STIFIn pada Pendidikan Anak Usia Dini (PAUD). Penelitian dilakukan di PAUD Lare Alit Kota Bandung, Indonesia. Penelitian ini akan menjawab pertanyaan penelitian yaitu mengapa menggunakan STIFIn dalam pendidikan karakter dan bagaimana strategi dalam mengimplementasikannya. Temuan dalam penelitian ini dapat menjadi acuan dasar dari penelitian-penelitian berikutnya terkait bagaimana strategi dalam menerapkan STIFIn untuk mendukung Pendidikan Karakter dalam konteks pendidikan formal di sekolah, baik tingkat PAUD ataupun pada tingkat lanjutannya.

\section{METODOLOGI}

Penelitian ini adalah penelitian kualitatif yang menggunakan teknik wawancara mendalam (in-depth interview) untuk mengumpulkan data utama, dan dilengkapi observasi lapangan. Alasan pemilihan teknik wawancara mendalam, karena menurut Boyce \& Neale (2006), bahwa teknik ini sangat cocok diterapkan untuk mengeksplorasi permasalahan tertentu secara komprehensif, sehingga didapatkan gambaran yang lengkap terkait apa saja yang dilakukan dalam sebuah program dan mengapa hal itu dilakukan. Dengan demikian, dalam penelitian ini para peneliti dapat memahami bagaimana penerapan STIFIn secara komprehensif. Agar pertanyaan yang diajukan melalui wawancara mendalam dapat tergali secara komprehensif, pada tahap awal peneliti menentukan framework terkait STIFIn berdasarkan literatur yang ada yaitu dengan mengidentifikasi tema utama dalam penerapan STIFIn. Tema utama ini akan menjadi guidance pada saat wawancara dilakukan. Di sisi lain, peneliti juga melakukan observasi pendahuluan di lokasi penelitian untuk mengidentifikasi stakeholders kunci terkait program, yang dapat menjadi informan.

Penelitian dilakukan di Lembaga Pendidikan Anak Usia Dini Lare Alit Bandung atau PAUD Lare Alit Bandung, Jawa Barat, Indonesia. Kegiatan wawancara dilakukan pada awal bulan Agustus 2020. Total informan pada penelitian ini berjumlah 5 orang, yaitu terdiri dari kepala sekolah dan 4 orang guru. Informan mencakup seluruh aktor yang berperan dan terlibat secara langsung dalam proses pendidikan karakter menggunakan STIFIn di lokasi penelitian. Dalam penelitian kualitatif tidak dikenal istilah validitas dan reliabilitas, namun kredibilitas (credibility) dan keterpercayaan (trustworthiness) yang ditingkatkan melalui berbagai teknik seperti variasi penggunaan metode, durasi penelitian yang lama, variasi jenis data, variasi informan sebagai sumber data dan lain-lain (Assarroudi, 2018; Creswell, 2014; Miles et al., 2014; Saldaña, 2011). Dalam penelitian ini, kredibilitas dan keterpercayaan ditingkatkan melalui penggunaan variasi jenis data dan variasi informan. Variasi jenis data yang digunakan adalah transkrip wawancara dan foto dokumentasi aktivitas. Sedangkan variasi informan dilakukan dengan mewawancarai informan yang memiliki berbagai peranan seperti yang ditampilkan pada Tabel 1. Data yang didapatkan dari variasi jenis data dan variasi informan kemudian ditriangulasi (dianalisis kesamaan, perbedaan, identifikasi tematema pokok dan kemudian digeneralisasi. Tahapan triangulasi juga merupakan salah satu 
langkah untuk meningkatkan kredibilitas data yang didapatkan dari metode penelitian kualitatif (Saldaña, 2011).

\section{Tabel 1. Spesifikasi Informan}

\begin{tabular}{cl}
\hline Informan & \multicolumn{1}{c}{ Spesifikasi } \\
\hline \multirow{2}{*}{ A } & $\begin{array}{l}\text { Kepala Sekolah yang terlibat secara umum dalam pembelajaran. Telah bergabung } \\
\text { sejak PAUD Lare Alit Bandung berdiri pada tahun 2013. Total pengalaman di } \\
\text { lingkungan PAUD adalah 12 tahun. }\end{array}$ \\
\hline B & $\begin{array}{l}\text { Guru penanggung jawab sentra balok. Telah bergabung sejak PAUD Lare Alit } \\
\text { Bandung berdiri. Total pengalaman di lingkungan PAUD adalah 9 tahun. }\end{array}$ \\
\hline C & $\begin{array}{l}\text { Guru penanggung jawab sentra persiapan. Telah bergabung sejak PAUD Lare Alit } \\
\text { Bandung berdiri. Total pengalaman di lingkungan PAUD adalah 14 tahun. }\end{array}$ \\
\hline D & $\begin{array}{l}\text { Guru penanggung jawab sentra bahan alam. Pengalaman mengajar di PAUD Lare } \\
\text { Alit Bandung adalah 3 tahun. }\end{array}$ \\
\hline E & Pengalaman mengajar di PAUD Lare Alit Bandung adalah 3 tahun. \\
\hline
\end{tabular}

Setelah dilakukan pengambilan data, data ditriangulasi dengan cara menganalisisnya terlebih dahulu menggunakan directed content analysis (Assarroudi et al., 2018). Proses analisis data dilakukan dalam tiga langkah: 1) menyimak rekaman wawancara satu per satu dan menganalisisnya sesuai dengan tema, 2) mengelompokkan tema, dan menyintesis temuan terkait STIFIn, 3) merumuskan strategi implementasi STIFIn. Seluruh proses metodologi yang dilakukan dalam penelitian ini diilustrasikan dalam Gambar 3.

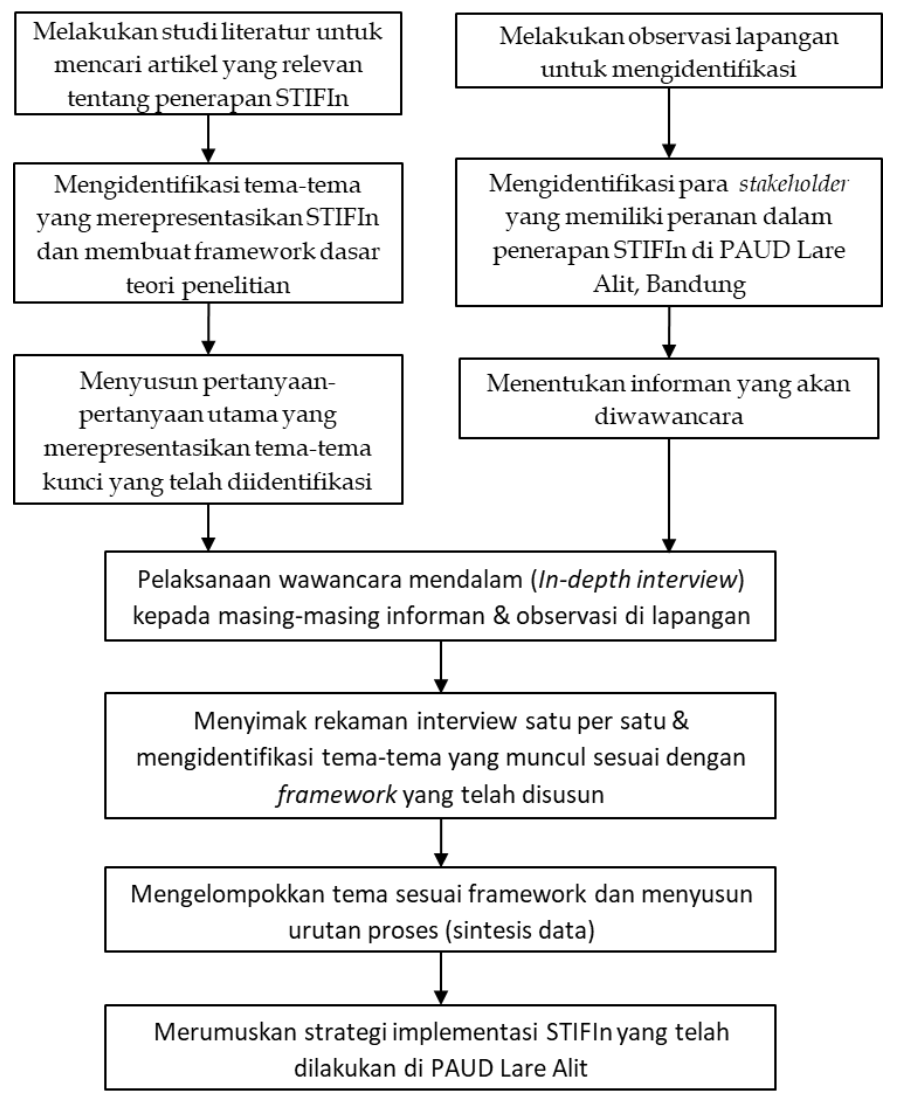

\section{Gambar 3. Proses Penelitian}

\section{HASIL DAN PEMBAHASAN}

Berdasarkan temuan dari wawancara, model pembelajaran yang diselenggarakan di PAUD Lare Alit Bandung (PAUD-LAB) adalah model pembelajaran sentra. Kegiatan 
pembelajaran dalam model pembelajaran sentra menggunakan pendekatan yang berfokus pada anak didik (Mutiah, 2012, p. 133). Model ini dilakukan melalui kegiatan bermain yang mampu menstimulus aspek-aspek kecerdasan anak didik dan diarahkan serta direncanakan dengan baik oleh guru (Ubaidillah, 2018). Ketika penelitian ini dilakukan, sentra yang diselenggarakan di PAUD-LAB ada tiga, yaitu Sentra Persiapan, Sentra Bahan Alam, dan Sentra Balok. Pada tahun 2017, PAUD-LAB mulai menerapkan STIFIn, termasuk dalam model pembelajaran sentra yang telah dilakukan selama ini. Setiap anak didik diwajibkan untuk mengikuti proses identifikasi dengan STIFIn atau dengan menunjukkan sertifikat hasil identifikasi jika pernah mengikutinya. Proses identifikasi ini dilakukan oleh PAUD-LAB pada awal penerimaan anak didik sebelum mengikuti kegiatan pembelajaran. Dalam penelitian ini juga ditemukan bahwa setiap guru di PAUD-LAB juga mengikuti proses identifikasi dengan menggunakan STIFIn. Sehingga para guru bisa belajar memahami diri sendiri dan saling memahami antara sesama guru.

\section{Pengenalan Karakteristik Anak Didik}

Sebelum penggunaan STIFIn di PAUD-LAB, dari hasil wawancara, terdapat 3 informan yang menyatakan bahwa untuk memahami karakteristik dan potensi setiap anak didik adalah proses yang membutuhkan waktu dan tidak mudah, serta terdapat kemungkinan salah dalam memahaminya. Ketiga informan tersebut sudah menjadi guru di sekolah tersebut sejak awal berdiri dan belum menggunakan STIFIn. Lebih lanjut, disebutkan bahwa potensi kesalahan dalam memahami anak didiknya sangat besar kemungkinannya. Padahal guru harus memahami karakteristik anak didiknya secara maksimal agar dapat mendidik anak didik dengan baik (Mustoip et al., 2018, p. 5), sehingga interaksi pembelajaran menjadi lebih efektif dalam mencapai tujuan pembelajaran (Zebua, 2020). Namun sejak mengimplementasikan STIFIn, para guru dapat mengidentifikasi potensi genetik setiap anak didiknya sejak awal, bahkan sejak sebelum kegiatan pembelajaran dimulai. STIFIn memberikan kemudahan kepada para guru untuk memahami karakteristik anak didik. Dengan demikian, peran STIFIn dalam Social Cognitive Theory (SCT) adalah sebagai identifikasi personal atau internal seseorang yang akan dilakukan proses perubahan atau pembentukan karakternya melalui pembelajaran.

Hasil dari identifikasi potensi genetik, ketika dikaitkan dengan komponen karakter, akan membantu dalam memberikan gambaran mengenai potensi komponen karakter pada setiap pribadi anak didik. Selain itu, akan memberikan gambaran mengenai komponen karakter yang perlu mendapatkan perhatian secara khusus untuk dikembangkan. Contohnya anak didik dengan kepribadian genetik Te dan Ti memiliki kecenderungan lebih mudah dalam menggunakan logika sesuai dengan umurnya dan menjelaskan sebab akibat (Hiday, 2017, p. 122). Sehingga anak didik tersebut memiliki potensi yang besar dalam mengembangkan moral knowing berdasarkan perkembangannya. Namun, di sisi lain memiliki kecenderungan yang membutuhkan pengembangan terkait sisi rasa (Hiday, 2017), sehingga membutuhkan bimbingan secara khusus untuk mengembangkan moral feeling dalam pembentukan karakternya. Berbeda halnya dengan anak didik berkepribadian genetik Fe dan $\mathrm{Fi}$, yaitu memiliki kecenderungan lebih mudah dalam pengembangan terkait rasa (Hiday, 2017), sehingga dalam pengembangan komponen moral feeling merupakan bagian dari potensi genetiknya. Namun di sisi lain membutuhkan kemampuan untuk mengembangkan kemampuan logikanya (Hiday, 2017), sehingga dapat memahami pengetahuan tentang nilainilai dengan baik.

\section{Pemilihan Strategi Pembelajaran}

Setelah pengenalan karakteristik anak didik dilakukan, pada tahap selanjutnya, identifikasi personal yang dihasilkan oleh STIFIn digunakan untuk menentukan cara yang tepat dan paling maksimal dalam kegiatan pembelajaran setiap anak didik. Penerapan berbagai pendekatan yang berbeda tersebut dilakukan oleh para guru di PAUD-LAB secara 
personal, sehingga setiap anak didik memperoleh perlakuan yang berbeda. Terdapat lima pendekatan yang diterapkan untuk dapat memfasilitasi seluruh tipe kepribadian genetik anak didik. Kelima pendekatan tersebut adalah learning by doing, simulasi, logika, perasaan dan spontan. Beberapa dokumentasi terkait pendekatan yang dilakukan ditunjukkan pada Gambar 4.

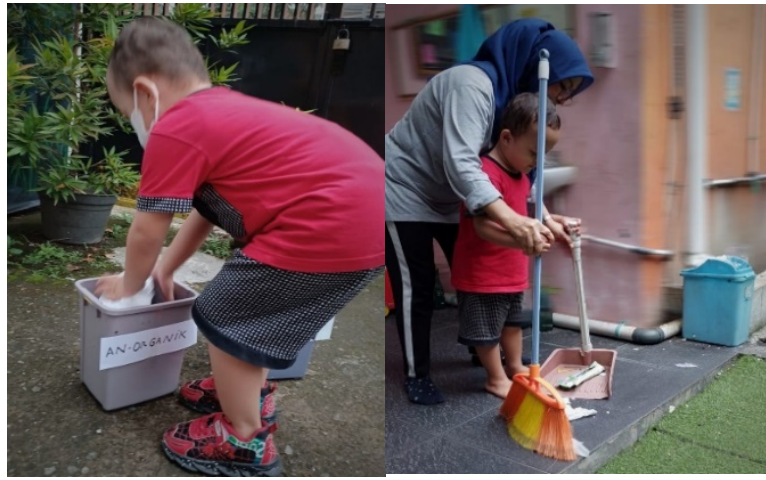

(a)Learning by doing; (b) Simulasi

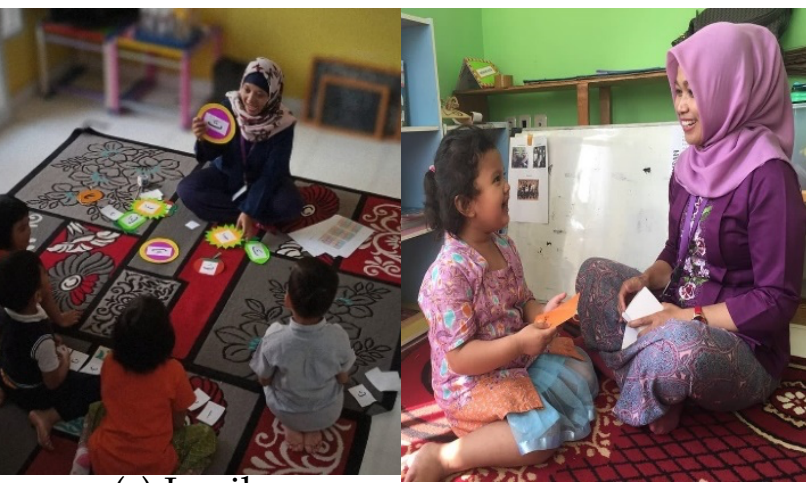

(c) Logika

(d) Perasaan

Gambar 4. Pendekatan yang dilakukan di PAUD Lare Alit berdasarkan karakteristik genetik Anak Didik yang diidentifikasi menggunakan STIFIn

Contoh pendekatan learning by doing yang dilakukan di PAUD-LAB adalah guru memberikan contoh secara langsung terkait aktivitas tertentu. Misalnya guru mencontohkan aktivitas memilah sampah dengan cara menunjukkan langsung jenis sampahnya dan guru membuang sampah di tempat sampah, sesuai dengan jenisnya. Kemudian, siswa diminta untuk menirunya (Gambar 4.a). Hal ini dilakukan beberapa kali hingga siswa dapat melakukannya secara mandiri. Pendekatan ini sejalan dengan yang disarankan oleh Hiday (2017), bahwa pendekatan learning by doing sangat cocok diterapkan untuk siswa dengan kepribadian genetik Sensing (Se \& Si). Pendekatan simulasi berupa visualisasi diterapkan dengan cara menempelkan gambar-gambar yang menunjukkan praktik pemilahan sampah di dekat tempah sampah. Menurut pengelola sekolah, visualiasi diterapkan untuk anak dengan kepribadian genetik Intuiting (Ie \& Ii). Dengan demikian, siswa Intuiting dapat belajar melalui gambar tersebut, selain juga praktik learning by doing yang diterapkan bersama-sama. Pemetaan ini sesuai dengan yang disarankan oleh Hiday (2017) bahwa siswa dengan kepribadian genetik Intuiting akan lebih mudah belajar melalui visualisasi. Jika dikaitkan dengan konsep pendidikan karakter, pendekatan learning by doing dan simulasi berhubungan erat dengan komponen karakter moral action dikonsepkan oleh Lickona (1991). Aspek pengembangan moral action terjadi dalam proses pembiasaan terhadap aktivitas tertentu yang dilakukan secara terus menerus (Lickona, 1991, p. 62), sedangkan pada simulasi, contoh perilaku disajikan dalam visualisasi yang diberikan secara terus menerus (Hiday, 2017).

Contoh pendekatan logika yang diterapkan pada PAUD-LAB dengan cara menjelaskan secara logis terhadap suatu aktivitas tertentu. Misalnya, terkait aktivitas pemilahan sampah, guru menjelaskan tentang sifat sampah yang kotor dan bau. Oleh karena itu sampah harus dibuang di tempat sampah dan dipisahkan antara sampah basah (organik) dan sampah kering (sampah anorganik). Menurut beberapa informan, pedekatan logika digunakan untuk memfasilitasi siswa dengan kepribadian genetik Thinking, sesuai dengan yang diindikasikan oleh Hiday (2017). Dalam kacamata pendidikan karakter berdasarkan teori Lickona (1991), pendekatan logika berkaitan erat dengan komponen moral knowing. Implementasi hal ini dapat berupa guru memberikan pengetahuan-pengetahuan dan kesadaran yang berkaitan dengan cinta kebersihan. 
Contoh pendekatan perasaan yang dilakukan guru di PAUD-LAB dengan cara menyampaikan aktivitas tertentu dengan melibatkan ekspresi yang menunjukkan emosional dan mengaitkan dengan akibat-akibat yang ditimbulkan jika hal itu tidak dilakukan. Dalam hal aktivitas pemilahan sampah, guru akan mengajak berbicara siswa secara personal dan memberikan mimik muka untuk menguatkan penjelasan mengapa mereka harus membuang sampahnya di tempat yang benar. Guru mengaitkan dengan adanya kemungkinan ketidaknyamanan yang bisa dirasakan siswa itu sendiri atau teman-teman yang lain jika siswa tersebut tidak mau membuang sampah sesuai dengan tempat yang disediakan. Pendekatan ini, menurut teori pendidikan karakter, merupakan komponen dari moral feeling (Lickona, 1991). Guru menyentuh hati nurani siswa dan membangkitkan rasa empati serta mendorong untuk mencintai hal-hal baik yang mencerminkan karakter moral feeling. Pendekatan perasaan merupakan pendekatan yang sesuai dengan kepribadian genetik feeling (fe \& fi) seperti yang diindikasikan oleh Hiday (2017).

Pendekatan yang bersifat spontan diterapkan di PAUD-LAB dengan cara memberikan pancingan-pancingan yang mendorong respon anak terhadap suatu aktivitas. Pendekatan spontan merupakan perwujudan dari yang dilakukan dalam ketiga komponen karakter. Menurut para informan, pendekatan spontan merupakan pendekatan yang sangat tepat untuk anak dengan kepribadian genetik Insting, yang senada dengan yang dinyatakan oleh Hiday (2017).

Implementasi setiap pendekatan dilakukan disesuaikan dengan kebutuhan dan perkembangan dari setiap siswa. Ada saat keseluruhan pendekatan dilakukan secara terintegrasi, dan ada saat lain yang hanya beberapa pendekatan yang lebih difokuskan. Pendekatan yang tepat akan membantu anak didik untuk memiliki motivasi dan keyakinan diri dalam mewujudkan suatu perilaku yang diharapkan (Ormrod et al., 2017; Santrock, 2011; Zebua \& Suhardini, 2021).

Berdasarkan pendekatan tersebut, selanjutnya dapat dilakukan metode yang paling tepat. Seperti contoh penerapan metode reward $\mathcal{E}$ punishment bagi anak didik dengan mesin kecerdasan Thinking, yaitu dengan menetapkan aturan yang jelas. Karena anak didik Thinking fokus dan taat pada aturan yang melibatkan konsekuensi secara logis atas tindakan yang dilakukan (Hiday, 2017). Oleh karena itu, PAUD-LAB menerapkan aturan-aturan yang sudah ditetapkan dan disampaikan kepada siswa sejak awal, serta selalu diingatkan secara berkala. Cara penyampaian dan pemberian reward $\mathcal{E}$ punishment dilakukan dengan menerapkan pendekatan-pendekatan berdasarkan kepribadian genetik yang telah dijelaskan sebelumnya.

Kegiatan pembelajaran di PAUD-LAB tidak mengelompokkan para anak didik berdasarkan perbedaan kepribadian genetiknya. Namun penentuan rombongan belajar berdasarkan umur anak didik. Sehingga meskipun para anak didik yang memiliki keragaman kepribadian genetik, mereka tetap berada dalam satu rombongan belajar. Hal ini ditujukan agar setiap anak didik memiliki kemampuan dalam membangun interaksi sosial dan saling memahami perbedaan sejak dini. Selain itu, setiap anak didik juga akan mengalami keragaman pengalaman pembelajaran yang terjadi di setiap sentra yang berbeda tersebut. Hal ini berimplikasi dalam pembentukan komponen karakter dalam diri anak didik yang terlibat di dalamnya. Strategi ini akan membantu dalam memberikan pengetahuan tentang toleransi, kebaikan dan integritas yang merupakan bagian dari sub komponen karakter, yaitu knowing moral values (Lickona, 1991, p. 54). Strategi ini juga mengembangkan rasa empati dan selfcontrol sebagai bagian dari komponen moral feeling (Lickona, 1991).

Penerapan perangkat kepribadian genetik STIFIn tidak mengubah posisi dan peranan sentra di PAUD-LAB, tetapi secara umum metode pembelajaran sentra mengakomodir pembelajaran bagi keragaman kepribadian genetik yang ada. Dengan demikian, berdasarkan teori SCT (Bandura, 1999; Dewar et al., 2012), STIFIn di PAUD-LAB berfungsi sebagai salah satu landasan dalam mendukung pembentukan lingkungan pendidikan atau pembentukan karakter anak didik. STIFIn menyediakan metode dan pendekatan yang sinkron dengan potensi dan karakteristik anak didik. Sehingga membantu para guru dalam pembentukan karakter anak didik secara humanis dan tepat sasaran (Poniman, 2009). Berdasarkan temuan 
dalam penelitian ini, dapat dinyatakan bahwa implementasi STIFIn dapat diselenggarakan dengan memaksimalkan sarana dan prasarana yang ada. Sehingga sekolah tidak diwajibkan untuk melakukan penambahan fasilitas pendukung lainnya. Karena, yang berperan penting dalam pembelajaran yang menerapkan perangkat kepribadian genetik STIFIn adalah pendekatan dan metode serta kreatifitas para guru.

\section{Kompetensi Guru tentang STIFIn}

Berdasarkan hasil wawancara, 4 dari 5 informan sependapat bahwa tingkat keberhasilan dalam pengasuhan dan pembelajaran anak didik sangat tergantung pada kompetensi setiap guru mengenai STIFIn. Kompetensi tersebut akan memengaruhi kemampuannya dalam melaksanakan pendekatan dan memilih metode yang tepat. Kemudian pada tahap selanjutnya, para guru dapat menentukan arah yang beragam dan kreatif dalam pembinaan karakter setiap anak didik. Ada anak didik yang membutuhkan bimbingan pembiasaan yang terus menerus setelah memperoleh pengetahuan moral yang mendalam. Di sisi lain, ada anak didik yang membutuhkan bimbingan pengetahuan moral setelah mendapatkan pembiasaan dari praktek-praktek yang dilakukannya. Ada juga anak didik yang memiliki kemampuan dalam mengembangkan rasa, namun sulit dalam memahami nilai-nilainya secara logis. Namun sayangnya, dalam penelitian ini masih terdapat guru yang belum begitu memahami tentang STIFIn, bahkan masih ragu-ragu mengenai identifikasi kepribadian genetik.

Tabel 2. Peran STIFIn Dalam Pembentukan Karakter Anak didik di PAUD Lare Alit

\begin{tabular}{|c|c|}
\hline $\begin{array}{c}\text { Komponen Karakter } \\
\text { dalam SCT }\end{array}$ & Peran STIFIn \\
\hline Personal/Internal & $\begin{array}{l}\text { - membantu guru memahami karakteristik \& potensi anak didik. } \\
\text { - menghemat waktu dalam mempelajari karakteristik \& potensi anak } \\
\text { didik. } \\
\text { - membantu dalam memberikan gambaran mengenai potensi komponen } \\
\text { karakter dalam diri anak didik dan komponen karakter yang } \\
\text { memerlukan perhatian secara khusus untuk dikembangkan. }\end{array}$ \\
\hline Lingkungan & $\begin{array}{l}\text { - membantu guru mencari pendekatan dan metode yang tepat dalam } \\
\text { menggali potensi komponen karakter dalam diri anak didik dan } \\
\text { mengembangkan komponen karakter yang memerlukan perhatian } \\
\text { secara khusus untuk dikembangkan. } \\
\text { - membangun interaksi yang saling memahami, bukan mengelompokkan } \\
\text { atau membedakan anak didik. } \\
\text { - pendekatan lebih utama dibandingkan fasilitas. }\end{array}$ \\
\hline Perilaku & $\begin{array}{l}\text { semakin tinggi kompetensi guru tentang STIFIn akan memengaruhi } \\
\text { kreativitasnya, sehingga guru lebih mudah membina komponen karakter } \\
\text { yang membutuhkan pengembangan berdasarkan kepribadian genetik. }\end{array}$ \\
\hline
\end{tabular}

Berdasarkan teori SCT (Bandura, 1999; Dewar et al., 2012), tingkat pemahaman guru tentang STIFIn akan meningkatkan pencapaian terhadap karakter anak didik melalui mediator lingkungan dan personal. Peran STIFIn dalam pembentukan karakter yang dibagi berdasarkan komponen-komponen dalam teori SCT dapat terlihat pada Tabel 2.

\section{Pengaruh Lingkungan Luar}

PAUD-LAB melakukan penilaian perkembangan anak didik termasuk dalam hal perkembangan karakternya khususnya terkait dengan sosial emosi anak didik. Secara berkala, perkembangan ini akan dilaporkan kepada orang tua anak didik melalui buku komunikasi 
yang disediakan oleh pihak sekolah. Apabila ditemukan kesenjangan antara laporan sekolah dengan keadaan anak didik di lingkungan rumah, maka pihak sekolah akan melakukan analisa. Analisa ini ditujukan untuk mencari penyebab kesenjangan tersebut.

Salah satu penyebab kesenjangan yang ditemukan oleh para guru adalah adanya perbedaan cara pendekatan dan metode yang dilakukan. Ketika orang tua dari anak didik tidak melakukan pendekatan yang sesuai dengan potensi dan karakteristik anak didik tersebut, maka anak didik tersebut sulit menerima keadaan lingkungan yang tidak sesuai dengan karakteristiknya itu. Selanjutnya anak didik tersebut cenderung melakukan tindakan yang mengarah kepada tindakan yang kontraproduktif.

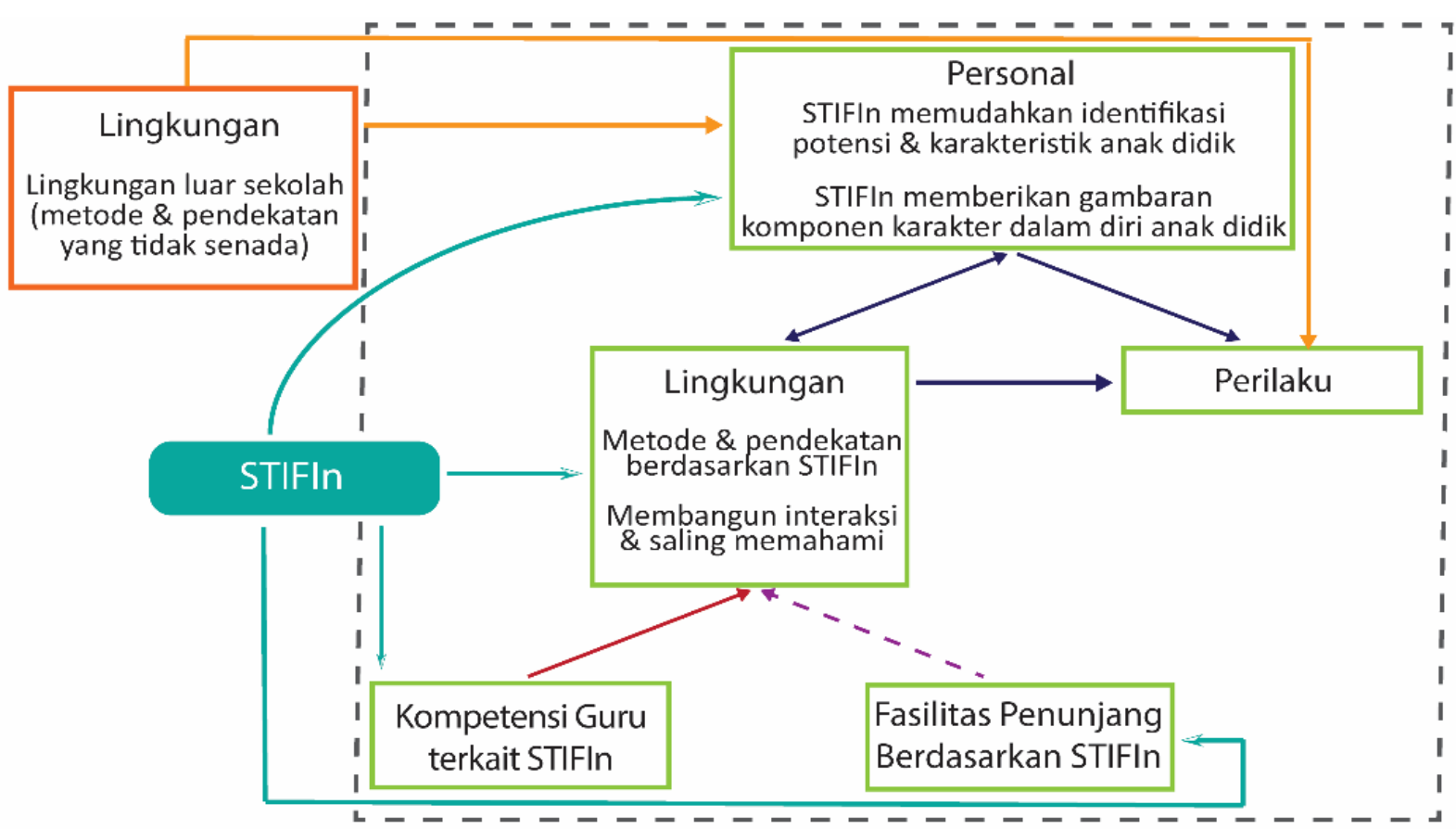

Gambar 5. Hubungan STIFIn dalam Pendidikan Karakter

Selain itu, pada penelitian ini juga ditemukan beberapa kondisi yang bersifat outlier. Salah satunya, ditemukan sebuah kondisi berupa seorang anak didik dengan kepribadian genetik tertentu, tetapi arah perkembangan karakternya tidak sesuai dengan hasil yang diharapkan dalam STIFIn. Dalam kasus outlier ini, anak didik tersebut memiliki kepribadian genetik Ti, berdasarkan hasil tes STIFIn. Seharusnya anak didik dengan kepribadian genetik Ti lebih fokus dan lebih mudah memahami dibandingkan anak didik Fi (Hiday, 2017). Namun setelah ditelusuri lebih lanjut, pihak sekolah menyatakan bahwa perkembangan anak didik yang tidak sesuai dengan harapan tersebut diakibatkan karena situasi lingkungan rumahnya yang bertentangan dengan potensi genetik anak didik tersebut.

Anak didik mendapatkan lingkungan yang tidak sesuai akibat ketidakharmonisan kedua orangtuanya. Ketika lingkungan yang dibangun di sekitar anak didik tidak cocok dengan kepribadian genetik anak didik, maka potensi yang dimilikinya tidak bisa berkembang maksimal, bahkan dapat berpotensi menghasilkan kepribadian yang kontraproduktif (Poniman, 2009). Hal ini menunjukkan pentingnya koordinasi antara pihak sekolah dan keluarga untuk memberikan lingkungan yang sejalan dan harmonis, untuk memaksimalkan pembentukan karakter yang tepat.

Berdasarkan uraian di atas, maka dapat digambarkan hubungan implementasi STIFIn dan variabel-variabel SCT yang berperan dalam pembentukan karakter ditunjukkan pada Gambar 5.

\section{Tahapan Strategi}


Berdasarkan uraian di atas, penelitian ini menunjukkan bagaimana strategi pendidikan karakter dengan mengimplementasikan STIFIn dalam prosesnya. Dapat disimpulkan bahwa, penerapan STIFIn dalam pendidikan karakter dilakukan melalui beberapa tahap, seperti yang ditunjukkan pada Gambar 6. Tahap pertama adalah mempersiapkan para guru agar memiliki kemampuan tentang pendekatan-pendekatan berbasis STIFIn. Bersamaan dengan itu, para guru juga diidentifikasi kepribadian genetiknya. Tahap selanjutnya berupa identifikasi kepribadian genetik para anak didik yang dilakukan sejak awal sebelum anak didik mengikuti kegiatan pembelajaran. Kemudian data identifikasi tersebut diedarkan kepada seluruh guru yang terkait dengan kegiatan pembelajaran anak didik tersebut agar dipelajari oleh para guru. Dengan demikian, para guru mudah dalam memahami potensi anak didiknya dan menentukan pendekatan yang tepat (Mustoip et al., 2018).

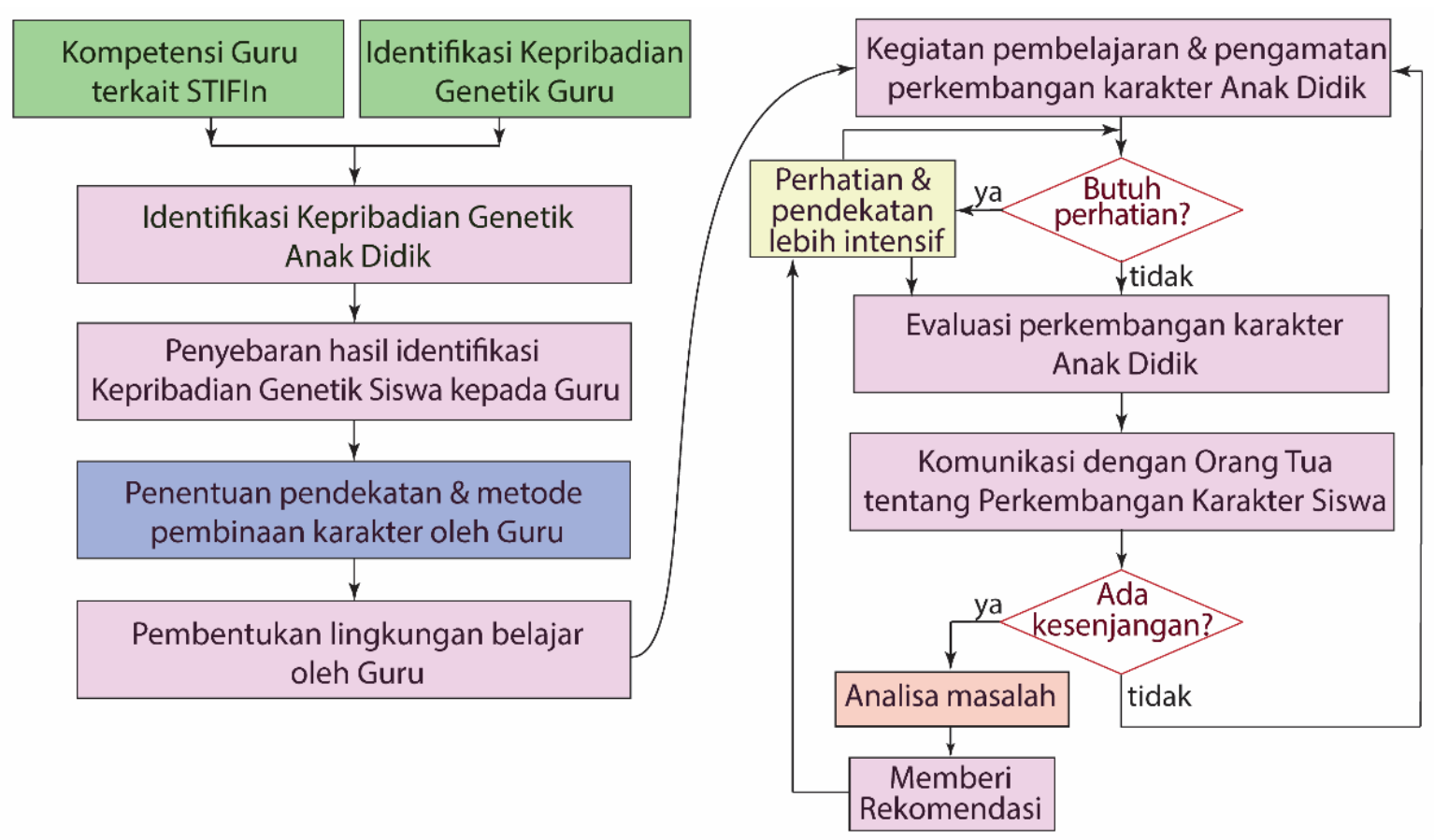

\section{Gambar 6. Strategi Implementasi STIFIn dalam Penguatan Pembentukan Karakter}

Tahap berikutnya adalah penentuan pendekatan dan metode dalam pembentukan lingkungan pembelajaran yang mendukung pembinaan karakter berdasarkan potensi kepribadian genetik setiap anak didik. Dalam hal ini, para guru berusaha menyiapkan situasi dalam sentra pembelajaran yang bisa mengakomodasi seluruh kepribadian genetik yang ada. Kemudian dalam kegiatan pembelajarannya, para guru memperhatikan perkembangan karakter dan keadaan setiap anak didik.

Tahap berikutnya adalah penentuan pendekatan dan metode dalam pembentukan lingkungan pembelajaran yang mendukung pembinaan karakter berdasarkan potensi kepribadian genetik setiap anak didik. Dalam hal ini, para guru berusaha menyiapkan situasi dalam sentra pembelajaran yang bisa mengakomodasi seluruh kepribadian genetik yang ada. Kemudian dalam kegiatan pembelajarannya, para guru memperhatikan perkembangan karakter dan keadaan setiap anak didik.

Selanjutnya melakukan evaluasi berkala terhadap perkembangan karakter anak didik. Apabila ada anak didik yang membutuhkan perhatian lebih, maka para guru akan berusaha melakukan pendekatan yang lebih intensif. Para guru juga harus mampu memahami penyebab adanya anak didik yang memiliki perkembangan karakter yang tidak sesuai dengan 
hasil identifikasi STIFIn, sehingga dapat membantu anak didik tersebut untuk memaksimalkan perkembangan karakternya.

Selanjutnya, para guru melakukan komunikasi secara berkala kepada kedua orang tua para anak didik mengenai perkembangan sosial emosionalnya. Apabila ditemukan adanya kesenjangan antara karakter di sekolah dan di rumah, dapat diketahui dari evaluasi yang dikomunikasikan ini. Kemudian para guru dan orang tua melakukan konsultasi dalam menganalisa penyebab dari situasi tersebut. Para guru memberikan rekomendasi kepada orang tua agar memberikan lingkungan yang mendukung terhadap perkembangan karakter anak didik tersebut, sehingga antara lingkungan sekolah dan lingkungan rumah dapat bersinergi dengan maksimal.

Para guru juga harus selalu di tingkatkan kemampuannya mengenai STIFIn. Peningkatan kemampuan guru dilakukan melalui dorongan untuk membaca literatur dan diskusi antara sesama guru, serta pelatihan terkait STIFIn. Sehingga para guru memiliki kapasitas yang memotivasi untuk semakin kreatif dalam membantu pembentukan komponen-komponen karakter yang dibutuhkan oleh anak didik.

\section{SIMPULAN}

Pendidikan karakter membutuhkan strategi yang tepat untuk membentuk lingkungan belajar yang disesuaikan dengan potensi dan karakteristik anak didik. Dalam penelitian ini ditemukan bahwa perangkat kepribadian genetik STIFIn dapat membantu guru memahami potensi dan karakteristik anak didik sehingga memudahkan guru membentuk lingkungan belajar yang sesuai. Hasil wawancara dan observasi, menunjukkan bahwa tingkat pemahaman para guru tentang personal genetik anak didik dan STIFIn sangat memengaruhi kemampuan dan pencapaiannya dalam membina karakter anak didiknya. Temuan dalam penelitian ini memberikan wawasan baru dalam pendidikan karakter berupa penggunaan STIFIn dapat mengoptimalkan pembangunan karakter anak didik yang menjadi salah satu tujuan utama pendidikan nasional di Indonesia.

\section{UCAPAN TERIMA KASIH}

Tim peneliti mengucapkan terimakasih kepada Kepala Sekolah, seluruh guru, dan pengelola PAUD Lare Alit Bandung yang telah mengizinkan dan berkenan memberikan berbagai data dan informasi yang dibutuhkan, sehingga penelitian ini dapat terlaksana dengan baik dan lancar.

\section{DAFTAR PUSTAKA}

Agung, B., \& Rustandi, D. (2017). Ini Gue Banget: Temukan Kekuatan Rahasiamu, Jadilah Apapun yang Kamu Mau. PT. Elex Media Komputindo.

Al-Qasimi, J. (2010). Buku Putih Ihya' Ulumuddin Imam Al-Ghazali. Darul Falah.

Alindra, A. L. (2018). Kajian Aksiologi Metode STIFIn dalam Pemetaan Mesin Kecerdasan Manusia. Jurnal Titian Ilmu: Jurnal Ilmiah Multi Sciences, 10(2), 64-73. https://doi.org/10.30599/iti.v10i2.206

Amri, M., \& Rahman, U. (2020). Description Of Structural Officers STIFIn Test Results Of UIN Alauddin Makassar. Lentera Pendidikan, 23(1), 1-8. https://doi.org/10.24252/lp.2020v23n1i1

Asbari, M., Nurhayati, W., \& Purwanto, A. (2019). Pengaruh Parenting Style dan Personality Genetic Terhadap Pengembangan Karakter Anak di PAUD Islamic School. JURNAL AUDI: Jurnal Ilmiah Kajian Ilmu Anak Dan Media Informasi PAUD, 4(2), 148-163.

Assarroudi, A., Heshmati Nabavi, F., Armat, M. R., Ebadi, A., \& Vaismoradi, M. (2018). Directed qualitative content analysis: the description and elaboration of its underpinning methods and data analysis process. Journal of Research in Nursing, 23(1), 42-55. https://doi.org/10.1177/1744987117741667 
Baharun, H., \& Adhimiy, S. (2019). STIFIn Method as Intelligence Machine in Enhancing Children's Intelligence Potential in Pesantren. TARBIYA, 6(2), 233-250. https://doi.org/10.15408/tjems.v6i2.9247

Bandura, A. (1999). Social Cognitive Theory: An Agentic Perspective. Asian Journal of Social Psychology, 2, 21-41. https://doi.org/10.1111/1467-839X.00024

Boyce, C., \& Neale, P. (2006). CONDUCTING IN-DEPTH INTERVIEWS: A Guide for Designing and Conducting In-Depth Interviews for Evaluation Input. Pathfinder International. https:// doi.org/10.1080/14616730210154225

Chen, I. J. (2011). The Behavioral Intention Of Preschool English Teachers In Participating In Early Childhood Education Training And Teaching Employment Services. International Journal of Arts \& Sciences, 4(25), 169-181. https://www.proquest.com/docview/1314751872

Creswell, J. W. (2014). Research Design: Qualitative, Quantitative, and Mixed Methods Approaches. Sage Publications.

Daradjat, Z. (2018). Ilmu Pendidikan Islam. Bumi Aksara.

Dewar, D. L., Lubans, D. R., Plotnikoff, R. C., \& Morgan, P. J. (2012). Development and Evaluation of Social Cognitive Measures Related to Adolescent Dietary Behaviors. International Journal of Behavioral Nutrition and Physical Activity, 9(36), 1-10. https://doi.org/10.1186/1479-5868-9-36

Frye, M., Lee, A. R., LeGette, H., Mitchell, M., Turner, G., \& Vincent, P. F. (2002). Character Education: Informational Handbook \& Guide for Support and Implementation of the Student Citizen Act of 2001 (Character and Civic Education). NC Character Education, Dept of Public Instruction.

Helmawati. (2017). Pendidikan Karakter Sehari-hari. Remaja Rosdakarya.

Hiday, M. (2017). I Iknow You: Kenali Bahasa Cinta Orang Tercinta, Raih Keluarga Sukses Mulia. STIFIn Institute.

Jawas, Y. bin A. Q. (2019). Adab \& Akhlak Penuntut Ilmu. Pustaka At-Taqwa.

Josephson, M. S., \& Hanson, W. (2004). The Power of Character (2nd ed.). Unlimited Publishing LLC.

Kemdikbud. (2017). Penguatan Pendidikan Karakter Jadi Pintu Masuk Pembenahan Pendidikan

Nasional.

https://www.kemdikbud.go.id/main/blog/2017/07/penguatan-pendidikankarakter-jadi-pintu-masuk-pembenahan-pendidikan-nasional

Lickona, T. (1991). Educating For Character: How Our Schools Can Teach Respect and Responsibility. Bantam Books.

Lickona, T., Schaps, E., \& Lewis, C. (2007). CEP's Eleven Principles of Effective Character Education. Character Education Partnership. https://eric.ed.gov/?id=ED505086

Miles, M. B., Huberman, A. M., \& Saldaña, J. (2014). Qualitative Data Anlaysis: A Method Sourcebook (3rd ed., Vol. 112). Sage Publications.

Mustoip, S., Japar, M., \& Zulela, M. S. (2018). Implementasi Pendidikan Karakter. Jakad Media Publishing. https://doi.org/10.31227/osf.io/qft7g

Mutiah, D. (2012). Psikologi Bermain Anak Usia Dini. Kencana Prenadamedia.

Oktaviany, V., \& Halim, I. (2020). Penerapan Konsep Manajemen Berbasis Genetik pada Peningkatan Kinerja Sekolah Inklusi. JIP: Jurnal Ilmu Pendidikan, 11(2), 154-163. https://doi.org/10.37640/jip.v11i2.102

Ormrod, J. E., Anderman, E. M., \& Anderman, L. (2017). Educational Psychology: Developing Learners (9th ed.). Pearson Education Limited.

Poniman, F. (2009). STIFIn Personality. Yayasan STIFIn.

Poniman, F., \& Ariezta, M. (2019). Pancarona: Buku Pegangan Peserta WSL2. Yayasan STIFIn.

Poniman, F., \& Hadiyat, Y. (2015). Manajemen HR STIFIn: Terobosan Untuk Mendongkrak Produktivitas. Gramedia Pustaka Utama. 
Poniman, F., \& Mangussara, R. A. (2013). Konsep Palugada: Apa Lu Mau Gua Ada. STIFIn Institute.

Powell, R. A., Honey, P. L., \& Symbaluk, D. G. (2009). Introduction to Learning and Behavior. Wadsworth.

Saldaña, J. (2011). Fundamentals of Qualitative Research: Understanding Qualitative Research. Oxford University Press.

Santrock, J. W. (2011). Educational Phychology (5th ed.). McGraw-Hill.

Schunk, D. H., \& DiBenedetto, M. K. (2020). Motivation and social cognitive theory. $\begin{array}{llll}\text { Contemporary } \quad \text { Educational } & \text { Psychology, }\end{array}$ https://doi.org/10.1016/i.cedpsych.2019.101832

Sundari, A., Mahrudin, A., \& Kholik, A. (2019). STIFIn Relationship with Profesionalism Teacher. Tadbir Muwahhid, 3(1), 1-13. https:// doi.org/10.30997/jtm.v3i1.1793

Tafsir, A. (2018). Pendidikan Karakter Ajaran Tuhan. Remaja Rosadakarya.

Ubaidillah, K. (2018). Pembelajaran Sentra BAC (Bahan Alam Cair) untuk Mengembangkan Kreativitas Anak; Studi Kasus RA Ar-Rasyid. Al-Athfal : Jurnal Pendidikan Anak, 4(2), 161-176. https://doi.org/10.14421/al-athfal.2018.42-04

Zebua, R. S. Y. (2020). The Strategy to Build Educative Interaction in Islamic Education on Online Learning Setting. Mudarrisa: Jurnal Kajian Pendidikan Islam, 12(2), 185-202. https:// doi.org/10.18326/mdr.v12i2.185-202

Zebua, R. S. Y. (2021). Pendidikan Karakter Melalui Pembelajaran Daring (Sebuah Model Konseptual). Tesis Tidak Diterbitkan. Bandung: Magister Pendidikan Islam Universitas Islam Bandung. http:// dx.doi.org/10.13140/RG.2.2.23229.79840

Zebua, R. S. Y., \& Suhardini, A. D. (2021). Model Pembelajaran Pendidikan Karakter: Panduan Operasional untuk Pembelajaran Online dan dilengkapi Contoh Implementasi pada Mapel PAI \& BP. Nas Media Pustaka.

Zebua, R. S. Y., \& Sunarti. (2020). The Strategy of Islamic Character Education with Role Model and Habituation Method on Online Learning. Ta'dib: Jurnal Pendidikan Islam, 9(2), 4558. https://doi.org/10.31219/osf.io/r3gw7

Zuchdi, D., Kuntoro, S. A., Kunprasetya, Z., Marzuki, Isroah, Sukanti, Widayati, A., Takarina, S. B., Prambiastuti, S., Sunarto, W., Sulistiya, B., Mujiarto, J., Gahara, K. S. W., Nugroho, S., Sarjono, Prihatini, E., Sumiyati, Sunarta, Siasah, M., ... Zamroni. (2012). Pendidikan Karakter: Konsep Dasar Dan Implementasi di Perguruan Tinggi. UNY Press. 